\title{
RELATIONSHIP BETWEEN CYBER PLAGIARISM AND THE BIG FIVE PERSONALITY TRAITS: AN EMPIRICAL STUDY IN A CHILEAN UNIVERSITY
}

\author{
P. RAMÍREZ-CORREA
}

Universidad Católica del Norte

patricio.ramirez@ucn.cl

Received 10/10/2016 - Accepted 30/08/2017

DOI: $10.15628 /$ holos.2017.5191

\begin{abstract}
The relationship between cyber plagiarism and the big five personality traits was explored in a sample of Chilean undergraduate students $(N=106)$. A questionnaire based on 44 items was used to measure the respondents' big five personality traits. In addition, a three-item scale was adopted to measure self-report on the behaviour of cyber plagiarism. The technique of
\end{abstract}

partial least squares regression was used for data analysis. The results indicate that an increase in cyber plagiarism $\left(R^{2}=.22\right)$ is significant and negatively related to the personality traits of conscientiousness, extraversion, and openness to experience, as also significant and positively related to the personality trait of neuroticism.

KEYWORDS: Plagiarism, Big five model, Latin America, Partial least squares.

\section{RELACIÓN ENTRE EL CIBER-PLAGIO Y LOS CINCO GRANDES RASGOS DE PERSONALIDAD: UN ESTUDIO EMPÍRICO EN UNA UNIVERSIDAD CHILENA}

\section{RESUMEN}

La relación entre el plagio cibernético y los cinco grandes rasgos de la personalidad fue explorada en una muestra de estudiantes universitarios chilenos $(N=106)$. Se utilizó un instrumento basado en 44 ítems para medir los cinco grandes rasgos de la personalidad de los encuestados. Adicionalmente, se adoptó una escala de tres ítems para medir el auto reporte sobre el comportamiento de plagio cibernético. La técnica de regresión de mínimos cuadrados parciales se utilizó para el análisis de datos. Los resultados indican que un aumento en el plagio cibernético $\left(R^{2}=0.22\right)$ está significativa y negativamente relacionado con los rasgos de personalidad responsabilidad, extroversión y apertura a la experiencia, como asimismo, significativa y positivamente relacionado con el rasgo de personalidad neuroticismo.

PALABRAS-CLAVE: Plagio, Modelo de los cinco grandes, Latino América, Regresión de mínimos cuadrados parciales. 


\section{INTRODUCTION}

In the global context, plagiarism is a constant temptation in academic life, and with the increasing content available through the Internet, this temptation has grown (Derby, 2008). Consequently, cyber plagiarism - the act of downloading papers from the Internet, in whole or partially, and submitting the paper as original work (Oliphant, 2002) - is today a major problem for the information society. Studies report that $32 \%$ of high school students have copied an Internet document for a class assignment, and $47 \%$ of college students have done plagiarism (Giluk and Postlethwaite, 2015). If that college students today plagiarize papers from the Internet regularly is a serious problem, as these students become researchers in the future, this problem can only get worse (Derby, 2008).

In Latin America, although there is an understanding of ethics internationally agreed regarding academic plagiarism, its institutions have been lagging behind in addressing the problems associated with this phenomenon (Vasconcelos et al., 2009). In addition, in recent years the objectification of research and higher promotion requirements imposed on Latin American academics, have led to the proliferation of plagiarism (Bonito, 2016). However, this may be starting to reverse. For instance, in Mexico 2015, it was decided to revoke a doctorate degree due to the existence of plagiarism in the thesis (Ramírez Bacca and Jiménez Patiño, 2016).

A few years ago the technique of copying and pasting was used frequently by cyber plagiarists. However, due to the more widespread use of plagiarism detection software, cyber plagiarists have become increasingly sophisticated, and their techniques are far more difficult to detect. Therefore, solutions to the problem of cyber plagiarism are related to know the motivations of this behaviour rather than just trying to control outcomes. In this sense, in the last decade there has been increasing interest in the role of personality to explain the unethical behaviour of university students in their own work, and in particular the model the big five personality traits has received attention in studies related to academic dishonesty (Giluk and Postlethwaite, 2015).

In this context, understanding the relationship between individual characteristics and this dishonest behaviour can be extremely useful. In particular, the aim of this study is to investigate the relationship between cyber plagiarism and the big five personality traits in a Latin American academic context.

The remainder of this article is structured as follows. First, a review of the literature on the model of the big five personality traits and their relationship with plagiarism is presented. This revision is used to develop hypotheses and research model. Then the section of materials and methods is described. Followed by this, the results and discussion of the application of a structural equation model to assess the research model are explained. And finally, the study conclusions are reported.

\section{BIG FIVE PERSONALITY TRAITS AS ANTECEDENT OF CYBER PLAGIARISM}

Proposed by Goldberg (Goldberg, 1990), the big five personality traits, also known as the five factor model, indicates that the salient features of an individual's personality can be described in terms of their scores on five domains: Agreeableness (A), Conscientiousness (C), Extraversion (E), Neuroticism ( $N$ ), and Openness to experience (O).

In the past 20 years the five factor model has been widely used (Matzler and Renzl, 2007), and has been recognized that it captures most of the individual differences in patterns of 
behaviour (De Feyter et al., 2012). Wikls and colleagues (Wilks et al., 2016) summarized the central findings of studies on the relationship between the big five and deviant behaviours. According to this review, low levels of agreeableness are related with deviant workplace behaviour, anti-social behaviour, white-collar crime, and academic dishonesty. Moreover, low levels of conscientiousness are related with deviant workplace behaviour, anti-social behaviour, and academic dishonesty. In additional, high levels of neuroticism are related with deviant workplace behaviour, anti-social behaviour, and white-collar crime. Furthermore, low levels of openness to experience are related with academic dishonesty; however, high levels of openness to experience are related with deviant workplace behaviour. Finally, high levels of extraversion are related with white-collar crime.

While there are studies that associate personality traits with cheating behaviours in different interpersonal contexts (Orzeck and Lung, 2005; Evans and Revelle, 2008; Wilks et al., 2016), within the numerous studies that have examined personality traits as predictors of overall Internet use (Mark and Ganzach, 2014), there are very few that focus on ethical behaviours in the use (Karim et al., 2009).

People with high score on agreeableness are good-natured, courteous, helpful, forgiving, generous, and co-operative (Goldberg, 1990). While agreeableness is not a determining factor in academic performance (O'connor and Paunonen, 2007), this trait is positively related to greater knowledge sharing (Matzler et al., 2008), which could allow for an original work with no plagiarism. In fact, a low score on agreeableness has been reported as a predictor of academic cheating (Williams et al., 2010; Wilks et al., 2016). Given this, we can hypothesize the relationship between agreeableness and cyber plagiarism as follows:

H1: High levels of agreeableness is negatively related to cyber plagiarism in an academic context.

Conscientiousness relates to being reliable, responsible, organized, hardworking and achievement oriented (Goldberg, 1990). In an interpersonal context, non-cheaters have highest scores on conscientiousness (Orzeck and Lung, 2005). In addition, conscientiousness is positively related both to ethical perceptions in business (Bratton and Strittmatter, 2013) and to learning orientation(Matzler and Mueller, 2011). Indeed, a low score on conscientiousness has been reported as a predictor of academic cheating (Williams et al., 2010; Wilks et al., 2016). In particular, literature indicates that conscientiousness predicts negatively to cyber plagiarism (Karim et al., 2009). Considering this, we can hypothesize the relationship between conscientiousness and cyber plagiarism as follows:

H2: High levels of conscientiousness is negatively related to cyber plagiarism in an academic context.

Extraversion is associated with being sociable, outgoing, energetic, talkative, and active (Goldberg, 1990). Recent studies indicate that extraversion is positively related both to academic performance (Akomolafe, 2013), and using the Internet for academic activities (Mark and Ganzach, 2014). In contrast, antisocial behaviour of people with low scores in extraversion may be more likely to engage in socially unacceptable behaviour, such as cyber plagiarism (Karim et al., 2009). In fact, cheaters use the Internet less frequently their academic activities (Trushell et al., 2012). Given this, we can hypothesize the relationship between extraversion and cyber plagiarism as follows: 
H3: High levels of extraversion is negatively related to cyber plagiarism in an academic context.

Neuroticism is associated with being anxious, depressed, embarrassed, emotional, angry, worried, and insecure (Goldberg, 1990). Literature indicates that neuroticism both predicts Internet use and is positively related to using Internet for academic activities (Mark and Ganzach, 2014). In addition, neuroticism is negatively related to ethical perceptions in business (Bratton and Strittmatter, 2013). Indeed, neuroticism predicts positively cyber plagiarism (Karim et al., 2009). Given this, we can hypothesize the relationship between neuroticism and cyber plagiarism as follows:

H4: High levels of neuroticism is positively related to cyber plagiarism in an academic context.

Individuals with high scores on openness to experience are imaginative, cultured, curious, original, open-minded, intelligent, and artistically sensitive (Goldberg, 1990). The desire to learn from individuals with high scores of openness to experience can lead to its orientation to acquire knowledge from honest work (Karim et al., 2009). In fact, openness to experience is positively related both to using Internet for academic activities (Mark and Ganzach, 2014) and to knowledge sharing (Matzler et al., 2008). Considering this, we can hypothesize the relationship between openness to experience and cyber plagiarism as follows:

H5: High levels of openness to experience is negatively related to cyber plagiarism in an academic context.

As a way to summarize this revision in Figure 1 is shown the research model of this study.

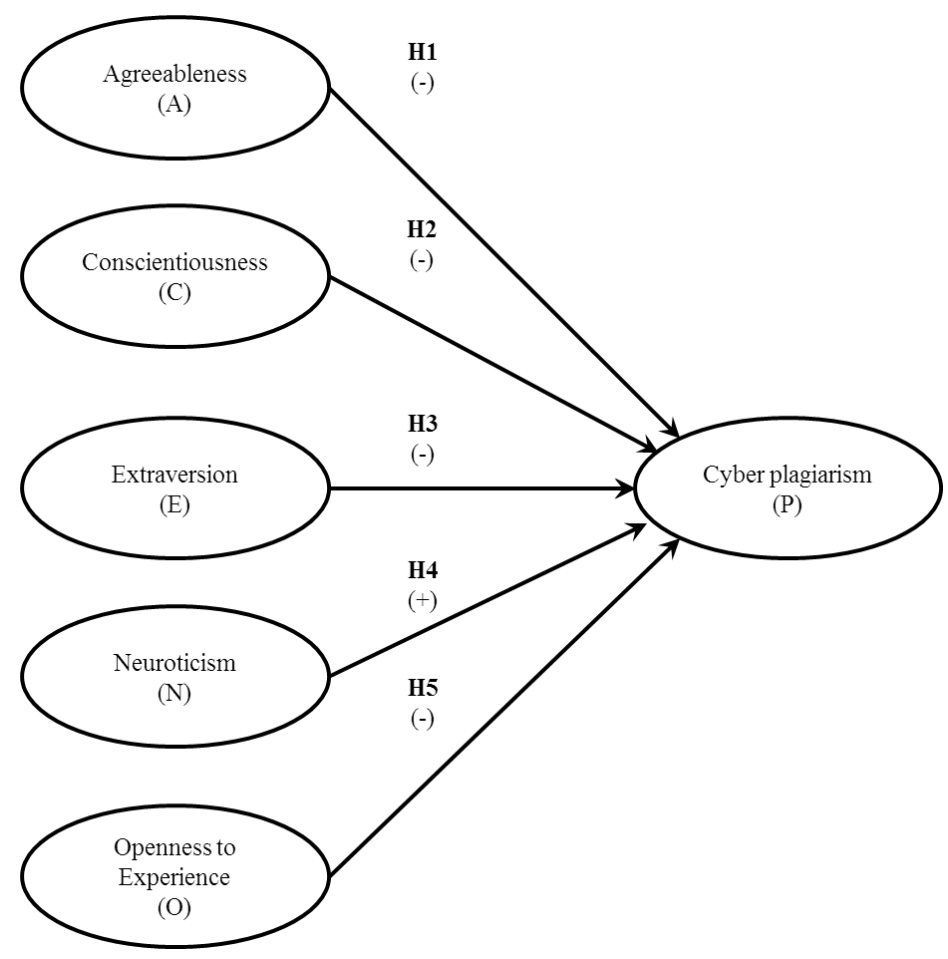

Figure 1: Research model and hypotheses. 


\section{MATERIALS AND METHODS}

Empirical research was based on a non-random sampling method. Data was collected in a Chilean University through a face-to-face survey in January 2014. The exclusion of invalid questionnaires provided a final sample size of 106 undergraduate students, 51 males (48.1\%) and 55 females (51.9\%). The average age of interviewees was 22.3 years \pm 2.15 (range 18-29 years).

The applied measurement scales have been tested in previous research. Specifically, the scale to measure the five traits was based on (John and Srivastava, 1999), and to measure cyber plagiarism a three-item scale was adapted from (Roig and Detommaso, 1995). All items of scales were measured on a 5-point Likert scale. The scale ranged from "1- highly disagree" to " 5 - highly agree".

Partial Least Squares (PLS) approach (Chin, 1998; Tenenhaus et al., 2005) was used to test the proposed research model. WarpPLS 4.0 software was used for this analysis (Kock, 2015).

\section{RESULTS AND DISCUSSION}

A PLS model is described by two sub-models: the measurement model and the structural model. Prior to conducting the structural model analysis it is necessary to analyze the reliability and validity of the measurement model. Reliability was evaluated by examining individual loads $(\lambda)$ of the items with their respective latent variables; items with $\lambda \geq 0.5$ were accepted (Hair Jr et al., 1986). As in previous research (Matzler and Renzl, 2007), the analysis of the reliability of the five personality traits did not deliver the expected results according to the standardized scales, and therefore they must be depurated by excluding some of the items with low $\lambda$. Table 1 shows scales after the depuration process.

Table 1: Measurement instrument after depuration.

\begin{tabular}{|c|c|}
\hline \multicolumn{2}{|c|}{ Items } \\
\hline \multicolumn{2}{|c|}{ Cyber plagiarism $(P)$} \\
\hline \multicolumn{2}{|c|}{ In writing a paper or doing homework for a college course ... } \\
\hline P1 & $\begin{array}{l}\text { I have taken one or two sentences from the Internet, changed } \\
\text { them slightly (e.g., transposed the subject and predicate, or } \\
\text { changed an article or preposition), and inserted this information } \\
\text { as my own writing. }\end{array}$ \\
\hline $\mathrm{P} 2$ & $\begin{array}{l}\text { I have taken several sentences from Internet, changed them } \\
\text { slightly (e.g., transposed the subject and predicate, or changed an } \\
\text { article or preposition), and inserted this information as my own } \\
\text { writing. }\end{array}$ \\
\hline P3 & $\begin{array}{l}\text { I have taken one or two sentences from Internet, changed them } \\
\text { moderately (e.g., transposed the subject and predicate, changed } \\
\text { articles and prepositions, used synonyms to substitute some but } \\
\text { not all of the terms, added a few words and short phrases), and } \\
\text { inserted this information as my own writing. }\end{array}$ \\
\hline \multicolumn{2}{|c|}{ I see myself as someone who... } \\
\hline \multicolumn{2}{|c|}{ Agreeableness (A) } \\
\hline A1 & Has a forgiving nature. \\
\hline A2 & Is considerate and kind to almost everyone. \\
\hline A3 & Likes to cooperate with others. \\
\hline \multicolumn{2}{|c|}{ Conscientiousness (C) } \\
\hline $\mathrm{C} 1$ & Does a thorough job. \\
\hline
\end{tabular}




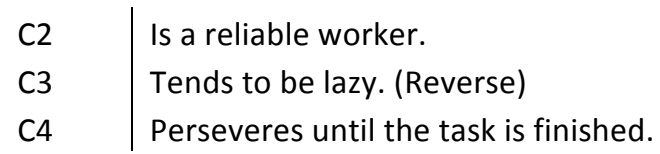

Extraversion (E)

E1 Is talkative.

E2 Generates a lot of enthusiasm.

E3 Tends to be quiet. (Reverse)

E4 Is sometimes shy, inhibited. (Reverse)

E5 Is outgoing, sociable.

Neuroticism ( $N$ )

N1 Is relaxed, handles stress well. (Reverse)

N2 Is emotionally stable, not easily upset. (Reverse)

N3 Remains calm in tense situations. (Reverse)

Openness to experience ( $O$ )

$01 \quad$ Has an active imagination.

O2 Is inventive.

O3 Likes to reflect, play with ideas.

All items were measured on a 5-point Likert scale. The scale ranged from "1- highly disagree" to "5- highly agree".

Table 2 shows the results from the cross-loading procedure for the sample, all indicators were significant at the 0.001 level.

Table 2: Loadings and cross-loadings for latent variables.

\begin{tabular}{l|c|c|c|c|c|c|l}
\hline Indicator & $\mathrm{P}$ & $\mathrm{A}$ & $\mathrm{C}$ & $\mathrm{E}$ & $\mathrm{N}$ & $\mathrm{O}$ & $p$ \\
\hline $\mathrm{P} 1$ & .928 & .091 & -.083 & -.014 & -.009 & -.038 & $* * *$ \\
$\mathrm{P} 2$ & .929 & .090 & -.039 & .028 & .043 & -.036 & $* * *$ \\
$\mathrm{P} 3$ & .806 & -.216 & .151 & -.012 & -.035 & .088 & $* * *$ \\
$\mathrm{~A} 1$ & -.103 & .798 & -.121 & .119 & -.143 & -.250 & $* * *$ \\
$\mathrm{~A} 2$ & .013 & .716 & .109 & -.281 & .139 & .160 & $* * *$ \\
$\mathrm{~A} 3$ & .182 & .628 & .093 & .136 & .096 & .277 & $* * *$ \\
$\mathrm{C} 1$ & .106 & .024 & .676 & .003 & .101 & .068 & $* * *$ \\
$\mathrm{C} 2$ & -.049 & -.014 & .713 & -.131 & .017 & -.040 & $* * *$ \\
$\mathrm{C} 3$ & -.020 & .105 & .817 & .085 & .049 & -.182 & $* * *$ \\
C4 & .005 & -.129 & .741 & .020 & -.138 & .217 & $* * *$ \\
$\mathrm{E} 1$ & .249 & .230 & -.057 & .694 & .146 & .093 & $* * *$ \\
E2 & .170 & .254 & -.060 & .521 & .073 & .301 & $* * *$ \\
E3 & -.149 & -.188 & .094 & .867 & .087 & -.023 & $* * *$ \\
E4 & -.028 & -.200 & .032 & .705 & -.164 & -.186 & $* * *$ \\
E5 & .082 & .273 & -.134 & .779 & -.097 & .011 & $* * *$ \\
N1 & .137 & -.110 & .030 & .154 & .525 & .078 & $* * *$ \\
N2 & .089 & -.182 & .058 & .181 & .653 & .067 & $* * *$ \\
N3 & -.069 & .106 & -.033 & -.115 & .920 & -.047 & $* * *$ \\
O1 & .033 & .051 & -.140 & .159 & .023 & .887 & $* * *$ \\
O2 & .093 & -.111 & .131 & .189 & -.342 & .644 & $* * *$ \\
O3 & -.063 & -.013 & .093 & -.218 & .091 & .871 & $* * *$ \\
\hline
\end{tabular}


To test for multicollinearity, the variance inflation factor (VIF) was calculated for each latent variable, in all cases the values remained below the recommended maximum value of 3.3 (Cenfetelli and Bassellier, 2009). Composite reliability (CR) and Cronbach's alpha coefficient (CA) were used as reliability indices of the latent variables, variables with $C R>.75$ were accepted. The convergent validity of latent variables was assessed by examining the average variance extracted (AVE), variables with AVE> .5 were accepted (Fornell and Larcker, 1981). Table 3 shows VIF, CR, $C A$, and AVE for each latent variable.

Table 3: Latent variable coefficients.

\begin{tabular}{l|r|r|r|r}
\hline Latent variable & VIF & \multicolumn{1}{c|}{ CR } & \multicolumn{1}{c}{ CA } & AVE \\
\hline Cyber plagiarism (P) & 1.171 & .919 & .866 & .791 \\
Agreeableness (A) & 1.256 & .759 & .557 & .515 \\
Conscientiousness (C) & 1.157 & .827 & .727 & .545 \\
Extraversion (E) & 1.366 & .842 & .783 & .522 \\
Neuroticism (N) & 1.208 & .752 & .607 & .516 \\
Openness to experience (O) & 1.216 & .847 & .754 & .654 \\
\hline CR, composite reliability coefficient for latent variable; CA, Cronbach's alpha coefficient for latent variable; VIF, variance inflation factor for latent \\
variable; AVE, average variance extracted for latent variable.
\end{tabular}

Discriminant validity of latent variables was tested analyzing whether the square root of AVE of each one was greater than the correlations with the rest of latent variables, Table 4 shows the results for the sample.

Table 4: Latent variable correlations.

\begin{tabular}{l|r|l|l|l|l|l}
\hline & \multicolumn{1}{l|}{$\mathrm{P}$} & $\mathrm{A}$ & $\mathrm{C}$ & $\mathrm{E}$ & $\mathrm{N}$ & $\mathrm{O}$ \\
\hline $\mathrm{P}$ &. $\mathbf{8 8 9}$ & & & & & \\
$\mathrm{A}$ & -.163 & .717 & & & & \\
$\mathrm{C}$ & -.160 & .263 & .739 & & & \\
$\mathrm{E}$ & -.324 & .275 & .304 & .723 & & \\
$\mathrm{~N}$ & .133 & .218 & .064 & -.186 & .718 & \\
$\mathrm{O}$ & -.216 & .296 & .153 & .250 & -.203 & .808 \\
\hline \multicolumn{5}{l}{ Square roots of AVE shown on diagonal. } \\
\hline
\end{tabular}

After analyzing validity and reliability of the measurement model, relationships between the constructs were addressed. Hypotheses were tested by examining path coefficients $(B)$ and their significance levels. The analysis algorithm used was Warp3 and the resampling method used was stable (Kock, 2015). The variance explained $\left(R^{2}\right)$ in the endogenous latent variables and $p$ values of regression coefficients (F-test) serve as indicators of the explanatory power of the model. Effect size (ES) was calculated for path coefficients, in all cases except A ES > .02. PLS analysis results for the structural model are summarized in Table 5 and Figure 2. 
Table 5: Structural model results.

\begin{tabular}{|c|c|c|c|}
\hline Dependent Variable: Cyber plagiarism (P) & \multicolumn{2}{|l|}{$\beta$} & ES \\
\hline$R^{2}$ & .218 & & \\
\hline$Q^{2}$ & .235 & & \\
\hline Agreeableness (A) & -.056 & & 010. \\
\hline Conscientiousness (C) & -.132 & $*$ & .028 \\
\hline Extraversion (E) & -.193 & $* * *$ & .068 \\
\hline Neuroticism (N) & .178 & $* * *$ & .042 \\
\hline Openness to experience $(\mathrm{O})$ & -.235 & $* * *$ & .071 \\
\hline
\end{tabular}

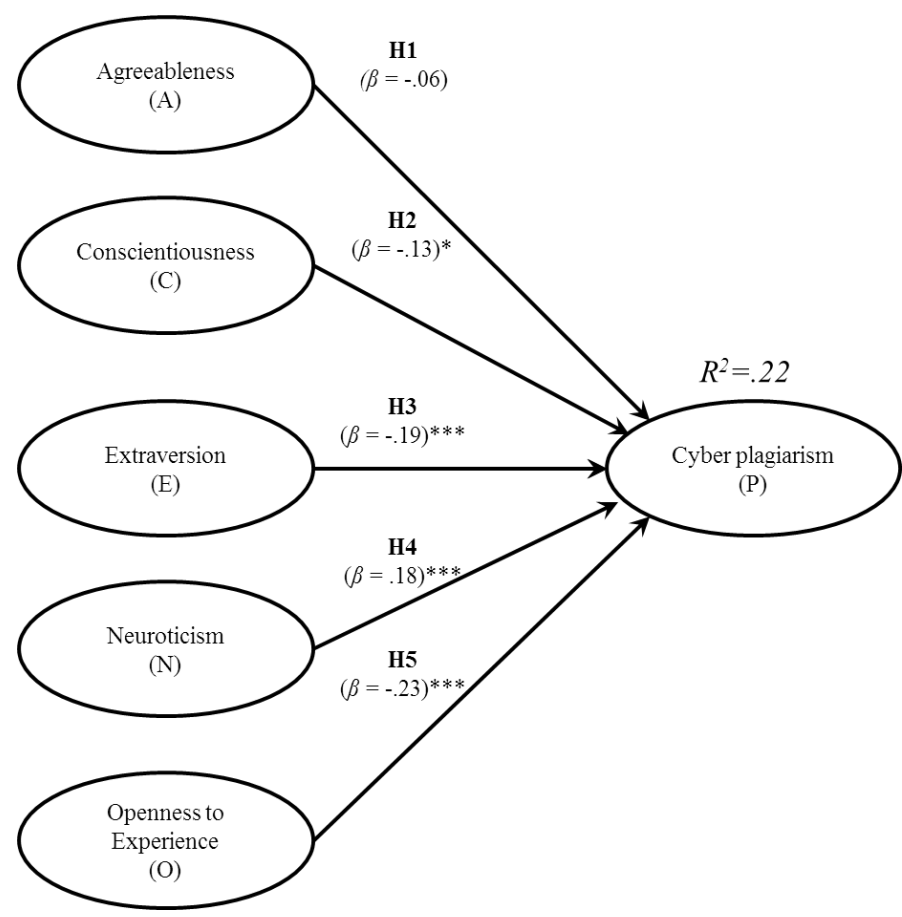

Figure 2: Results of the study.

$* \mathrm{p}<0.05 ; * * * \mathrm{p}<0.001$.

Table 6 shows the model fit indices calculated to globally assess the model. All fit indices have acceptable values.

Table 6: Model fit indices.

\begin{tabular}{l|c}
\hline Index & Value \\
\hline Average of path coefficient (APC) & $.159^{* * *}$ \\
Average of square root (ARS) & $.218^{* * *}$ \\
Average of variance inflation factor (AVIF) & 1.162 \\
Average of average variances extracted (AAVE) & .591 \\
Tenenhaus Goodness of fit (GoF) & .359 \\
\hline$* * * p<.001$. & \\
\hline
\end{tabular}


Based on these results hypotheses $\mathrm{H} 2, \mathrm{H} 3, \mathrm{H} 4$, and $\mathrm{H} 5$ are supported. Following these findings is discussed.

Overall, the study results indicate that research model is valid in Chile. The exception to this statement is the relationship between agreeableness and cyber plagiarism ( $\mathrm{H} 1)$. In particular, research findings indicate that the variables that predict cyber plagiarism are, in order of importance: openness to experience; extraversion; neuroticism; and conscientiousness.

In addition, we highlight three ideas. First, our results support other studies that indicate that low levels of conscientiousness (Wilks et al., 2016) and high levels of neuroticism (Karim et al., 2009) predict plagiarism. This finding confirms within Latin American context the role of these psychological traits as antecedents of academic plagiarism. Second, the results cannot support to other recent studies suggesting that low levels of agreeableness predict plagiarism (Wilks et al., 2016). Since there is an important number of studies support this idea (Giluk and Postlethwaite, 2015), we believe that this finding must be taken with caution. And third, the results reveal novel relationships between low levels of both openness to experience and extraversion, and perform cyber plagiarism. We believe that these findings, and especially the importance of these variables in the prediction of cyber plagiarism, may be associated with cultural differences of sample of this study in relation to samples of other studies reported in the literature.

\section{CONCLUSIONS}

This research was oriented to examination the relationship between cyber plagiarism and the big five personality traits in an academic context. The research model was tested in a sample of undergraduate student in a Chilean university.

Main conclusions drawn from this study are as follows:

(i) The measurement model was validated successfully.

(ii) The structural model supported four of the five hypotheses proposed.

(iii) Four personality traits predict cyber plagiarism $\left(R^{2}=.22\right)$.

(iv) The personality traits that increase cyber plagiarism are, in order of importance: low levels of openness to experience, low levels of extraversion, low levels of neuroticism, and low levels of conscientiousness.

We point out two limitations of this study. Firstly, the use of a non-random sampling method within a single organization limits the generalization of findings. Secondly, the validation of results requires a larger sample of individuals.

Finally, due to the lack of academic honesty in the Internet environment being a critical issue for higher education today (Underwood and Szabo, 2003), we believe that further studies would be useful to validate the research findings in other cultural and economic contexts.

\section{REFERENCES}

AKOMOLAFE, M. J. Personality Characteristics as Predictors of Academic Performance of Secondary School Students. Mediterranean Journal of Social Sciences, v. 4, n. 2, p. 657, 2013.

BONITO, J. C. La universidad Latinoamericana en la encrucijada: amenazas, desafíos y soluciones. Revista Historia de la Educación Latinoamericana, v. 18, n. 26, p. 241-277, 2016. 
BRATTON, V. K.; STRITTMATTER, C. To Cheat or Not to Cheat?: The Role of Personality in Academic and Business Ethics. Ethics \& Behavior, v. 23, n. 6, p. 427-444, Nov 2013.

CENFETELLI, R. T.; BASSELLIER, G. Interpretation of formative measurement in information systems research. Mis Quarterly, v. 33, n. 4, p. 689-707, 2009.

CHIN, W. W. The partial least squares approach for structural equation modeling. In: MARCOULIDES, G. A. (Ed.). Modern Methods for Business Research. Hillsdale, NJ: Lawrence Erlbaum Associates, 1998. p.295-336.

DE FEYTER, T. et al. Unraveling the impact of the Big Five personality traits on academic performance: The moderating and mediating effects of self-efficacy and academic motivation. Learning and Individual Differences, v. 22, n. 4, p. 439-448, 2012.

DERBY, B. Duplication and plagiarism increasing among students. Nature, v. 452, n. 7183, p. 2929, 2008.

EVANS, A. M.; REVELLE, W. Survey and behavioral measurements of interpersonal trust. Journal of Research in Personality, v. 42, n. 6, p. 1585-1593, 2008.

FORNELL, C.; LARCKER, D. F. Evaluating Structural Equation Models with Unobservable Variables and Measurement Error. v. 18, n. 1, p. 39-50, 1981.

GILUK, T. L.; POSTLETHWAITE, B. E. Big Five personality and academic dishonesty: A meta-analytic review. Personality and Individual Differences, v. 72, p. 59-67, 2015.

GOLDBERG, L. R. An alternative description of personality - The big-5 factor structure. Journal of Personality and Social Psychology, v. 59, n. 6, p. 1216-1229, Dec 1990.

HAIR JR, J. F.; ANDERSON, R. E.; TATHAM, R. L. Multivariate data analysis with readings. New York, NY: Macmillan Publishing Co., Inc., 1986.

JOHN, O. P.; SRIVASTAVA, S. The Big Five trait taxonomy: History, measurement, and theoretical perspectives. Handbook of personality: Theory and research, v. 2, n. 1999, p. 102-138, 1999.

KARIM, N. S. A.; ZAMZURI, N. H. A.; NOR, Y. M. Exploring the relationship between Internet ethics in university students and the big five model of personality. Computers \& Education, v. 53, n. 1, p. 86-93, Aug 2009.

KOCK, N. WarpPLS 5.0 user manual. Laredo, TX: ScriptWarp Systems, 2015.

MARK, G.; GANZACH, Y. Personality and Internet usage: A large-scale representative study of young adults. Computers in Human Behavior, v. 36, p. 274-281, Jul 2014.

MATZLER, K.; MUELLER, J. Antecedents of knowledge sharing - Examining the influence of learning and performance orientation. Journal of Economic Psychology, v. 32, n. 3, p. 317329, Jun 2011.

MATZLER, K.; RENZL, B. Personality traits, employee satisfaction and affective commitment. Total Quality Management \& Business Excellence, v. 18, n. 5, p. 589-598, 2007.

MATZLER, K. et al. Personality traits and knowledge sharing. Journal of Economic Psychology, v. 29, n. 3, p. 301-313, Jun 2008.

OLIPHANT, T. Cyber-plagiarism: Plagiarism in a digital world. Feliciter, v. 48, n. 2, p. 78-80, 2002.

ORZECK, T.; LUNG, E. Big-five personality differences of cheaters and non-cheaters. Current Psychology, v. 24, n. 4, p. 274-286, Win 2005.

O'CONNOR, M. C.; PAUNONEN, S. V. Big Five personality predictors of post-secondary academic performance. Personality and Individual differences, v. 43, n. 5, p. 971-990, 2007.

RAMÍREZ BACCA, R.; JIMÉNEZ PATIÑO, H. D. Plagiarism and Self-plagiarism. A Reflexion. HiSTOReLo. Revista de Historia Regional y Local, v. 8, n. 16, p. 273-283, 2016.

ROIG, M.; DETOMMASO, L. Are college cheating and plagiarism related to academic procrastination? Psychological Reports, v. 77, n. 2, p. 691-698, 1995. 
TENENHAUS, M. et al. PLS path modeling. Computational Statistics \& Data Analysis, v. 48, n. 1, p. 159-205, Jan 2005.

TRUSHELL, J.; BYRNE, K.; SIMPSON, R. Cheating behaviours, the Internet and Education undergraduate students. Journal of Computer Assisted Learning, v. 28, n. 2, p. 136-145, Apr 2012.

UNDERWOOD, J.; SZABO, A. Academic offences and e-learning: individual propensities in cheating. British Journal of Educational Technology, v. 34, n. 4, p. 467-477, Sep 2003.

VASCONCELOS, S. et al. Discussing plagiarism in Latin American science. EMBO reports, v. 10, n. 7, p. 677-682, 2009.

WILKS, D. C.; CRUZ, J. N.; SOUSA, P. Personality Traits and Plagiarism: an Empirical Study with Portuguese Undergraduate Students. Journal of Academic Ethics, v. 14, n. 3, p. 231-241, 2016.

WILLIAMS, K. M.; NATHANSON, C.; PAULHUS, D. L. Identifying and Profiling Scholastic Cheaters: Their Personality, Cognitive Ability, and Motivation. Journal of Experimental PsychologyApplied, v. 16, n. 3, p. 293-307, Sep 2010. 